International Journal of Social Sciences and Humanities
Available online at http://sciencescholar.us/journal/index.php/ijssh
Vol. 1 No. 3, December 2017, pages: $40 \sim 48$
e-ISSN: 2550-7001, p-ISSN: 2550-701X
http://dx.doi.org/10.21744/ijssh.v1i3.51

\title{
Collaboration as a Strategy for Poverty Alleviation
}

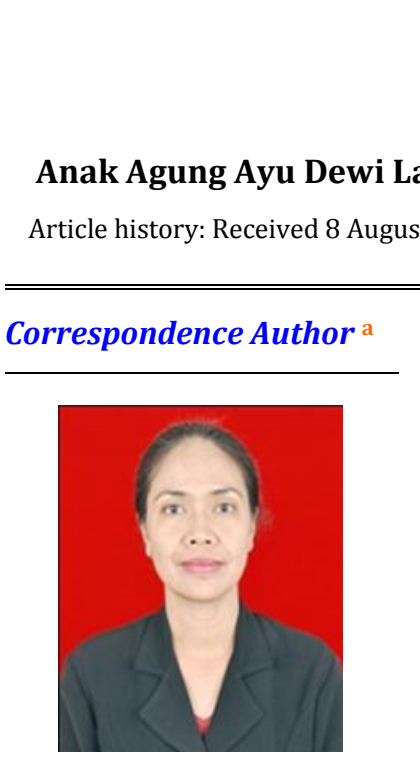

Keywords

Cooperation;

Coordination;

Collaboration;

Innovative strategy;

Poverty alleviation;
Accepted in revised form 9 September 2017; Approved 21 November 2017; Available online 1 December 2017
The poverty issue was very complex regarding various aspects of life, therefore, poverty alleviation was needed an involvement of the various parties. In order to be able to cooperate with various parties was required a deep cooperation. This descriptive qualitative research aims to analyze the cooperation of various parties in the poverty alleviation. The data were collected through interviews with the Poverty Alleviation Coordination Team and the key informant. The results show that cooperation in the poverty alleviation was limited in coordination between work units of the regional apparatus. The coordination was undertaken in the context of programming, implementing, and evaluating of the poverty alleviation. However, the coordination has not been maximized due without involving the private sector and universities who were also members of the poverty alleviation coordination team. The cooperation was more optimal when applying the collaboration principles. Therefore, a deeper cooperation was needed than just coordination, that was, in the form of collaboration. The collaboration in the form of collaboration between various parties could be an innovative strategy in the poverty alleviation.

e-ISSN : 2550-7001, p-ISSN : 2550-701X@ Copyright 2017. The Author. SS Journals Published by Universidad Técnica de Manabí.

This is an open-access article under the CC BY-SA 4.0 license (https://creativecommons.org/licenses/by-sa/4.0/) All rights reserved.

\footnotetext{
a Faculty of Social and Political Sciences, Warmadewa University, Jl. Terompong No. 24 Denpasar-Indonesia (agungdewilarantika@gmail.com)

b Faculty of Public Administration, Brawijaya University, Jl. MT Haryono, Malang-Indonesia

c Faculty of Public Administration, Brawijaya University, Jl. MT Haryono, Malang-Indonesia

d Faculty of Public Administration, Brawijaya University, Jl. MT Haryono, Malang-Indonesia
} 


\section{Contents}

Abstract

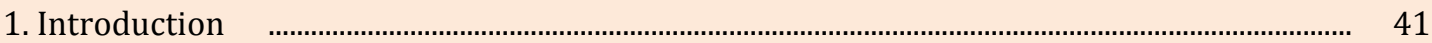

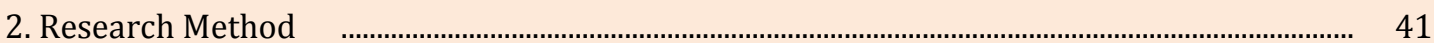

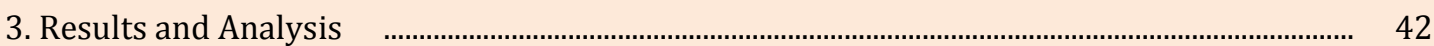

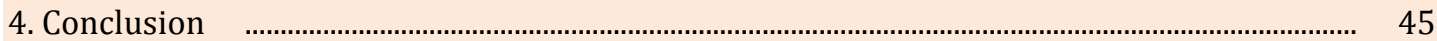

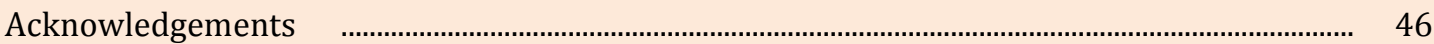

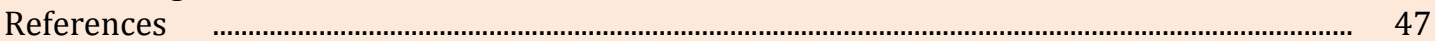

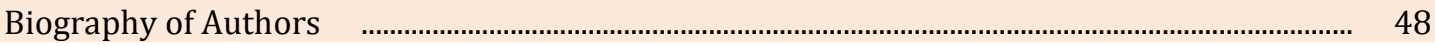

\section{Introduction}

The poverty is a complex issue due to poverty is not only about economics, education, health, but also social, cultural and even political. Therefore, the poverty requires serious handling involving various fields and parties. Thus, the poverty issue requires multisectoral handling with a strategy of countermeasures involving the many parties in an integrated manner. In accordance with the concept of governance, the interaction between the three main actors in the policy implementation, i.e. government, society, and private is a very important in the successful implementation of the policy itself.

In Indonesia, the poverty alleviation is a priority in development. The national poverty alleviation strategy is a common direction for governments, communities, the private sector, and various parties in promoting the national movement for the poverty alleviation. Some legal products are published as operational basis, unlike Presidential Decree No. 8 in 2002 on Poverty Reduction Committee; Presidential Decree No. 54 in 2005 on Poverty Alleviation Coordination Team; Presidential Decree No. 15 in 2010 on the Acceleration of Poverty Alleviation; Regulation of the Minister of Home Affairs No. 34 in 2009 concerning Guidelines for Establishment of Poverty Alleviation Coordination Team in Regency/City; and the Minister of Home Affairs Regulation No. 42 in 2010 on the Coordination Team for Provincial and District/City Poverty Alleviation.

Similarly, Badung Regency has established a Coordination Team for Regional Poverty Alleviation, due to although it has the highest revenue of the highest regions in Bali Province, it still has poor people even in small numbers. The number of poor people who fluctuated in the same range since the establishment of the Regional Poverty Alleviation Coordination Team (TKPKD) in 2009 (Badung Regent Decree No. 1924/03/HK/2009), i.e. in 2009 about 14,000 people, then increased in 2010 to 17,700 inhabitants, in 2011 amounted to 14,630 people, in 2012 fell to 12,830 inhabitants, but in 2013 rose to 14,540 inhabitants, in 2014 to 15,420 inhabitants, and in 2015 about 14,400 inhabitants. The situation is taken an action by the government of Badung Regency trying to cope with various poverty alleviation programs that are implemented for integration manner involving various sectors.

An integrated poverty alleviation efforts through the formation of TKPKD is expected to decrease poverty. The coordinating team of the regional poverty alleviation included the unit of local working (SKPD), private parties, and universities as the team members. A cooperation between sectors is expected to play an optimal role in the poverty alleviation. However, looking at existing poverty data, it appears that TKPKD coordination has not given optimal results, therefore, it is necessary to find a form of cooperation or more effective strategy in the poverty alleviation in Badung regency.

\section{Research Method}

The present study is the result of the qualitative research that aims to analyze the cooperation of various parties in the poverty alleviation. The research location is in Badung regency. The data is collected through interviews, observation, and documentation. An

Larantika, A. A. A. D., Zauhar, S., Makmur, M., \& Setyowati, E. (2017). Collaboration as a strategy for poverty alleviation. International Journal of Social Sciences and Humanities, 1(3), 40-48. https://doi.org/10.29332/ijssh.v1n3.51 
Interview is conducted with informants, in this case, coordination team of the poverty alleviation, including of unit of local working area (SKPD), private party (CSR), and college. An observation is through direct object observation and existing documentation related to cooperation in poverty alleviation activities. The data analysis used is descriptive qualitative that is described and analyze the data obtained for getting a conclusion.

\section{Results and Analysis}

The poverty alleviation policies implemented in Badung Regency are guided by the Minister of Home Affairs Regulation No. 34/2009 on Guidelines for the Establishment of Poverty Alleviation Coordination Team in Regency/City, the implementation of poverty reduction program in Badung regency in 2010 is implemented by the Poverty Alleviation Coordination Team (TKPK) Badung established based on Badung Regent Decree No. 1924/03/HK/2009 on December 29, 2009 the Establishment of Poverty Alleviation Coordination Team (TKPKD) Badung Regency. This institutional arrangement was subsequently updated in accordance with the Minister of Home Affairs Regulation No. 42/2010 on the Coordination Team for Poverty Alleviation of Provinces and Regency/City through the Decree of Badung Regent No. 1299/03/HK on May 4, 2011. The Poverty Alleviation Coordinating Team (TKPKD) a combination of the Unit of Local Working (SKPD) in Badung Regency, private parties, and universities as team members.

The concept of the poverty alleviation in Badung regency is carried out in a coordinated manner through synchronization, harmonization, and integrated policies and programs as well as coordination of SKPD programs implementation incorporated in TKPK. The poverty alleviation programs are grouped into three clusters which are pro-people programs included:

1. Family-based poverty alleviation program (emphasizing the fulfillment of the basic right to prioritize the fulfillment of the right to food, education, health services, and sanitation and health water).

2. Group-based poverty alleviation program (specific sector-based programs needed by societies categorized as underdeveloped areas).

3. Poverty alleviation programs based on empowerment of the small and medium enterprises (unlike financing or capital assistance, opening access to capital or marketing of products and assistance, as well as improving skills and business management).

In the poverty alleviation, TKPKD has a duty:

1. Coordinate family-based poverty alleviation policies and programs, including a) coordinating the formulation of the poverty alleviation strategies as the basis for the preparation of the Regional Medium-Term Development Plan (RPJMD) in the field of poverty alleviation; b) coordination of the Unit of Local Working or joint SKPD forum in the field of poverty alleviation in the preparation of SKPD Strategic Plan, Local Government Work Plan (RKPD), SKPD Work Plan; c) evaluating the implementation of the document formulation of the regional development plan in the field of the poverty alleviation.

2. Controlling the implementation of the poverty alleviation programs and activities in Badung regency includes the duty of controlling, monitoring, supervising, and follow-up on the achievement of the program objectives and poverty alleviation activities to be in accordance with regional development policies; controlling and monitoring the implementation of the program by SKPD which includes the realization of the target achievement, fund absorption and constraints faced; preparation of monitoring results of program implementation and program activities periodically; control and evaluation of program implementation; control and handling of the public complaints; preparing implementation reports and program achievements to the Regents and TKPK Provinces. 
The interviews and observations results indicate that cooperation in poverty alleviation in Badung regency is the coordination between SKPD existing in TKPKD, through the activity programs in accordance with their main duty and functions. When the household target has been established, each SKPD prepares an activity program in accordance with their respective duty and functions coordinated by BAPPEDA. Upon approval and agreement, the activities are undertaken by each SKPD and evaluated in the form of the accountability reports of activities and the use of funds. A coordination occurs during programming and evaluation.

Whereas, the coordination towards the private sector is not optimal, due to the involvement of the private sector in the poverty alleviation is still limited to the issue of funds and other assistance that can be provided by the private sector. The private parties involved in TKPKD are PT. Perum Angkasa Pura I, PDAM Badung Regency, Bali Villas Association, PT. Bank Pembangunan Daerah Bali, Melia Bali Villas Resort, BTDC Nusa Dua, BPC PHRI Badung Regency, DPD ASITA Bali Province. Although the private sector is listed as a TKPKD member, but not involved in programming, they are only involved when the assistance provided will be channeled to beneficiaries, in this case, the poor household. Even some of them do not know their help will be given to whom in what form.

The coordination towards the universities, it is also very limited only if the government asks for input advice from universities about the program plan that has been prepared by the government. Universities provide inputs on poverty assessments, empowerment, and programs that can be provided in poverty alleviation but are not involved in program implementation and evaluation.

Coordination according to G.R. Terry (2002) is defined as asynchronous and orderly effort to provide the right number and timing and direct the execution to produce a uniform and harmonious action on a predetermined goal. There are three activities in coordination (Brinkerhoff and Crosby, 2002), which are sharing information, sharing resources, and acting together. These elements become important in coordination, therefore, the parties coordination know what to do, how to allocate their respective resources to then act together in achieving common goals. Good coordination occurs when coordinated obstacles unlike the threats to autonomy, lack of agreement on tasks, and vertical-horizontal conflicts can be overcome with these elements.

The coordination process among members is not optimal yet for the poverty alleviation team in Badung regency encourages to find a solution in cooperation process as innovation in poverty alleviation. An innovation according to Stephen Robbins (1994), is a new idea that is applied to initiate or improve a product or process and services. Meanwhile, according to Everett M. Rogers (1983), innovation is an idea, suggestion, and practice that are based and accepted as something new by a person or a particular group to be applied or adopted. Thus, an innovation is the development of new ideas or suggestions that are accepted for being implemented.

Looking at the existing coordination among the government, private, and universities in the poverty alleviation policy coordination team, it is interesting to know more effective collaborative innovation in poverty alleviation activities. The form of cooperation depends on the purpose of cooperation done, how the implementation process, how the structure and how the management of existing resources from the parties who cooperate. According to Bob Williams (2003), there is cooperation called networking, cooperation, coordination, and collaboration. The more detail the cooperation stages, the stronger relationship between the two parties who work together. Collaboration is a cooperation with details stages in terms of purpose, processes, structures and resource management, thus, it is considered as a more effective form of cooperation than any other form of cooperation. The cooperation form based on purpose, structure, processes, and resources according to Bob Williams, (2003) unlike in the following table:

Larantika, A. A. A. D., Zauhar, S., Makmur, M., \& Setyowati, E. (2017). Collaboration as a strategy for poverty alleviation. International Journal of Social Sciences and Humanities, 1(3), 40-48. https://doi.org/10.29332/ijssh.v1n3.51 
Table 1

Cooperation form based on purpose, structure, processes and resources.

\begin{tabular}{|c|c|c|c|c|}
\hline LEVEL & PURPOSE & STRUCTURE & PROCESS & RESOURCES \\
\hline Networking & $\begin{array}{l}\text {-Provide dialogue } \\
\text { and common } \\
\text { understanding } \\
\text {-Mutual } \\
\text { exchange to } \\
\text { support each } \\
\text { others' efforts } \\
\text {-Clearinghouse } \\
\text { for information } \\
\text {-Create } \\
\text { clearinghouse for } \\
\text { information } \\
\text {-Create base of } \\
\text { support }\end{array}$ & $\begin{array}{l}\text {-Non-hierarchical } \\
\text {-Loose/flexible } \\
\text { link } \\
\text {-Roles are } \\
\text { loosely defined } \\
\text {-Community } \\
\text { the action is } \\
\text { primary } \\
\text { link among } \\
\text { members }\end{array}$ & $\begin{array}{l}\text {-Low-key } \\
\text { leadership } \\
\text {-Minimal } \\
\text { decision } \\
\text { making } \\
\\
\text {-Little conflict } \\
\text {-Informal } \\
\text { Communication }\end{array}$ & $\begin{array}{l}\text {-Variable time } \\
\text {-Minimal skill } \\
\text {-Minimal support } \\
\text {-Minimal finance }\end{array}$ \\
\hline Cooperation & $\begin{array}{l}\text {-Match needs } \\
\text { and provide } \\
\text { coordination } \\
\text {-Limit duplication } \\
\text { of services } \\
\text {-Ensure that } \\
\text { tasks are done } \\
\text {-Limited joint } \\
\text { problem solving }\end{array}$ & $\begin{array}{l}\text {-Central team } \\
\text { acts as } \\
\text { communication } \\
\text { hub } \\
\text {-Semi-formal } \\
\text { links } \\
\text {-Links are } \\
\text { advisory } \\
\text {-Group seeks to } \\
\text { influence } \\
\text { decision making }\end{array}$ & $\begin{array}{l}\text {-Leaders who } \\
\text { facilitate } \\
\text {-Perhaps some } \\
\text { conflict } \\
\text {-Formal } \\
\text { Communication } \\
\text { within the } \\
\text { central team }\end{array}$ & $\begin{array}{l}\text {-Variable time } \\
\text {-Medium skill } \\
\text {-Medium support } \\
\text {-Variable finance }\end{array}$ \\
\hline Coordination & $\begin{array}{l}\text {-Share resources } \\
\text { to address } \\
\text { common issues } \\
\text {-Link resources } \\
\text { to achieve joint } \\
\text { goals } \\
\text {-Merge resource } \\
\text { base to create } \\
\text { something new } \\
\text {-More complex } \\
\text { problem solving }\end{array}$ & $\begin{array}{l}\text {-Central team } \\
\text { consists of } \\
\text { decision makers } \\
\text {-Roles are } \\
\text { defined } \\
\text {-Links are } \\
\text { formalized } \\
\text {-Group } \\
\text { participates in } \\
\text { decision making }\end{array}$ & $\begin{array}{l}\text {-Autonomous } \\
\text { leadership } \\
\text { focused on } \\
\text { issue } \\
\text {-Central and } \\
\text { subgroup } \\
\text { decision making } \\
\text {-Frequent and } \\
\text { clear } \\
\text { Communication }\end{array}$ & $\begin{array}{l}\text {-Medium to high } \\
\text { time } \\
\text {-Some skills at } \\
\text { high level } \\
\text {-High support } \\
\text {-Variable finance }\end{array}$ \\
\hline Collaboration & $\begin{array}{l}\text {-Shared vision } \\
\text { and goals } \\
\text {-Build } \\
\text { interdependent } \\
\text { system to } \\
\text { address issues } \\
\text { and } \\
\text { opportunities } \\
\text {-Complex } \\
\text { problem solving } \\
\text {-Share resources }\end{array}$ & $\begin{array}{l}\text {-Consensus is } \\
\text { used in shared } \\
\text { decision making } \\
\text {-Roles, time, and } \\
\text { evaluation are } \\
\text { formalized } \\
\text {-Links are formal } \\
\text { and written into } \\
\text { agreements } \\
\text {-Group is a } \\
\text { decision making } \\
\text { structure }\end{array}$ & $\begin{array}{l}\text {-High } \\
\text { leadership, } \\
\text { trust level, and } \\
\text { productivity } \\
\text {-Ideas and } \\
\text { decisions } \\
\text { equally shared } \\
\text {-Highly } \\
\text { developed } \\
\text { communication }\end{array}$ & $\begin{array}{l}\text {-High time } \\
\text { - Complex skills } \\
\text { at high level } \\
\text {-High levels of } \\
\text { support } \\
\text {-Variable finance }\end{array}$ \\
\hline
\end{tabular}


Since, the poverty alleviation is a complex issue involving various sectors, the suggested form of cooperation is not limited to coordination. In accordance to the study Local Government officials' Views on Intersectoral Collaboration within Their Organization - A Qualitative Exploration, (2014) by Anna-Marie Hendriks, Mary W.J. Jansen, Jessica S. Gubbels, Nanne K. De Vries, Gerard Molleman, Stef P.J. Kremers, revealed that cross-sectoral cooperation (ISC) is defined as collaboration between health and non-health officials of the local government to provide more effective outcomes for the development an integration policy that addresses the issues of the public health and poverty generally.

Wendy Ranade and Bob Hudson in his article entitled Conceptual Issues in Inter-Agency Collaboration (2014). Cooperation between agencies/institutions is not a new thing in the government, previously the cooperation is more open and involves various parties including the society. The good collaboration will enable the achievement of shared goals according to previous predictions. Due to in the collaboration process requires the cooperation in thinking or planning program, implementing up to evaluate the achievements program. There are six important things in the concept of collaboration according to Huxham and Siv Vangen (1996) included:

1. Managing aims: the collaboration purpose as the main reason for collaboration, as to the interests of the parties involved in collaboration and the rationale for collaboration.

2. Compromise: the view unifying aspect and perceptions of actors in terms of culture, values, and work.

3. Communication: an effective communication in the information sharing to avoid multiple meanings thus the parties who collaborate to understand what each desire.

4. Democracy and Equality: the decision-making process, determining who should be involved in the collaboration and form of accountability of each collaborating actor.

5. Power and Trust: in the present study intended the role of government work and the form of the private and public participation in the poverty alleviation.

6. Determination, Commitment, and Stamina: the commitment of actors to the poverty alleviation and sustainability of their collaboration.

Unlike the poverty alleviation involves the various sectors and requires more detailed collaboration and participation from various parties, a necessary collaborative form is a collaborative form. Taking into the six important points in the collaboration as mentioned above, will result in effective and efficient cooperative relations in countermeasures poverty. Therefore, the collaboration among members of the poverty alleviation team can be innovation strategy in the poverty alleviation.

\section{Conclusion}

Based on the above description, it can be concluded that poverty alleviation in Badung regency implemented in the form of coordination that occurs only between SKPD in the coordination team poverty alleviation area (TKPKD). An involvement of the private parties and universities as part of the team has not been maximized. Therefore, the results achieved from cooperation among team members is not optimal. In order to be able to achieve more optimal results should the government of Badung regency improve the form of internal team collaboration into collaboration, involving cooperation with private parties and universities as part of the team. Due to applying the principle of collaboration between government agencies, private, and universities, the network, cooperation, and coordination will be well done, thus the poverty alleviation in Badung regency can be more focused, effective, efficient, and sustainable. The collaboration can be offered as an innovative strategy of cooperation in poverty alleviation.

Larantika, A. A. A. D., Zauhar, S., Makmur, M., \& Setyowati, E. (2017). Collaboration as a strategy for poverty alleviation. International Journal of Social Sciences and Humanities, 1(3), 40-48.

https://doi.org/10.29332/ijssh.v1n3.51 


\section{Acknowledgements}

Our deep and sincere gratitude were presented to God for having granted us the ability and the opportunity to complete this paper. We would also like to thank our former lecturers and our friends for their support, their patience, their contribution, and their valuable input, therefore, this article could be completed. We would also thank I Wayan Suryasa as an advisor as well as editor in chief of IJMRA, Skirec and SS who has reviewed and approved this study to be published. 


\section{References}

Agranoff, R., \& McGuire, M. (2004). Collaborative public management: New strategies for local governments. Georgetown University Press. View in (Google Scholar) (Scopus)

Basak, A., \& Khanna, K. (2017). A Study on the Selection Criteria of Different Hotels of Delhi NCR in Accordance to the HR Policies and Market Trends. International Journal of Social Sciences and Humanities (IJSSH), 1(1), 27-38. View in (Google Scholar)

Beyerlein, M. M., Freedman, S., McGee, C., \& Moran, L. (2003). The ten principles of collaborative organizations. Global Business and Organizational Excellence, 22(2), 51-63. View in (Google Scholar) (Scopus)

Billaiya, R., Malaiya, S., \& Parihar, K. S. (2017). Impact of Socio Economic Trends on Students in Quality Education System. International Journal of Social Sciences and Humanities (IJSSH), 1(1), 16-20. View in (Google Scholar)

Bryson, J. M., Crosby, B. C., \& Stone, M. M. (2006). The design and implementation of Cross-Sector collaborations: Propositions from the literature. Public administration review, 66(s1), 44-55. View in (Google Scholar) (Scopus)

Cedeño, M. L. D., Arteaga, M. G. D., Pérez, A. V., \& Arteaga, M. L. D. (2017). Regulatory Framework for Renewable Energy Sources in Ecuador Case Study Province of Manabí. International Journal of Social Sciences and Humanities (IJSSH), 1(2), 29-42. View in (Google Scholar)

De Backer, G., Ambrosioni, E., Borch-Johnsen, K., Brotons, C., Cifkova, R., Dallongeville, J., ... \& Cats, V. M. (2003). European guidelines on cardiovascular disease prevention in clinical practice: third joint task force of European and other societies on cardiovascular disease prevention in clinical practice (constituted by representatives of eight societies and by invited experts). European heart journal, 24(17), 1601-1610. View in (Google Scholar) (Scopus)

Decree of Badung Regent No.1299 / 03 / HK / 2011 on the Establishment of Poverty Alleviation Coordination Team (TKPK) Badung Regency.

Ghosh, C. (2017). A Study on-Evaluating Marketing Strategies Adopted by Home Appliance for Economic Development in India. International Journal of Social Sciences and Humanities (IJSSH), 1(1), 9-15. View in (Google Scholar)

Government Regulation no.38 of 2008 on improving people's welfare and poverty reduction.

Huxham, C., \& Vangen, S. (1996). Working together: Key themes in the management of relationships between public and non-profit organizations. International Journal of Public Sector Management, 9(7), 5-17. View in (Google Scholar) (Scopus)

Kożuch, B. (2009). The culture of collaboration. Theoretical aspects. Journal of Intercultural Management, 1(2), 17-29. View in (Google Scholar) (Scopus)

Majumdar, D. (2006). Collaboration among government agencies with special reference to New Zealand: A literature review. Social Policy Journal of New Zealand, 27, 183. View in (Google Scholar) (Scopus)

Ministry of Home Affairs Regulation No.42 year 2010 on Coordination Team for Provincial and District / City Poverty Alleviation.

Presidential Decree No.124 of 2001 which was revised in Presidential Decree No.8 of 2002 on Poverty Alleviation Committee.

Presidential Decree No.15 of 2010 on the Acceleration of Poverty Alleviation.

Presidential Decree No.54 of 2005 on Poverty Alleviation Coordinating Team.

Suryasa, I. W., Prayoga, I. G. P. A., \& Werdistira, I. W. A. (2017). An Analysis of Students' Motivation Toward English Learning As Second Language Among Students In Pritchard English Academy (PEACE). International Journal of Social Sciences and Humanities (IJSSH), 1(2), 43-50. View in (Google Scholar)

Larantika, A. A. A. D., Zauhar, S., Makmur, M., \& Setyowati, E. (2017). Collaboration as a strategy for poverty alleviation. International Journal of Social Sciences and Humanities, 1(3), 40-48. 


\section{Biography of Author}

\begin{tabular}{|c|c|}
\hline & \\
\hline & 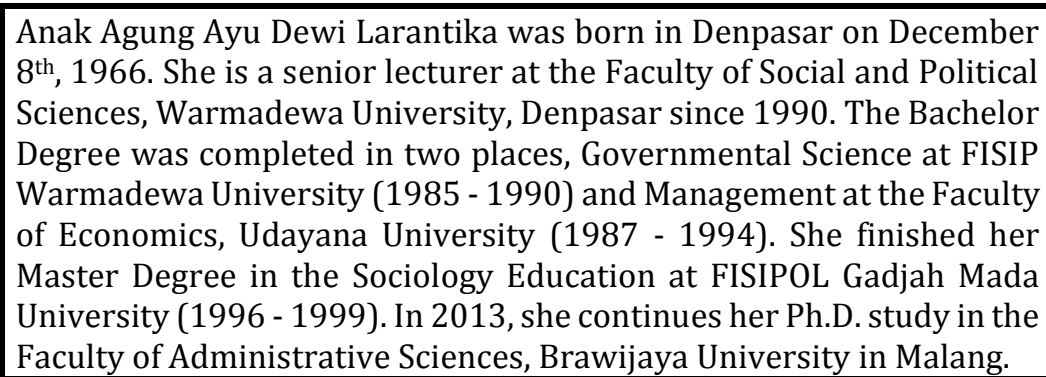 \\
\hline
\end{tabular}

